\title{
Socialization To The Internet: Who Is Teaching Our Children?
}

Diane H. Parente, Ph.D., Penn State Erie, USA

Matthew E. Swinarski, Ph.D., Penn State Erie, USA

Kathleen Noce, D.Ed., Penn State Erie, USA

\begin{abstract}
The introduction of technology into 21st century life has been fast and ubiquitous. The 2000 United States Census is filled with examples of increasing proportions of the American family who have access to computers and the internet. The issue of changes in our culture and the socialization of all parts of society bring logical questions about our children and technology. Where are they learning about the internet? Is the popular press correct in stating that there is a generational gap between parents and their children in socialization of technology? Where are they learning about the various uses of the Internet? This paper attempts to answer the question concerning who is teaching our children (about technology). Who is actually doing the socializing to technology?
\end{abstract}

Keywords: internet, adolescent socialization, computer usage

\section{INTRODUCTION}

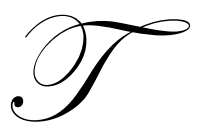

he introduction of technology into 21 st century life has been fast and ubiquitous. The 2000 United States Census is filled with examples of increasing proportions of the American families who have access to computers and the internet. For example, more than $56 \%$ of U.S. households were reported to have computers (Current Population Survey, 2001, Table 1A). In fact, in households with 15-17 year olds, more than $76 \%$ had a computer and over $68 \%$ had access to the Internet at home (Current Population Survey, 2001, Table 2A). Additionally, nine out of ten school age children have access to a computer and the Internet either through home or at school. Computer, and specifically the Internet, is an important tool, as well as an influence, in our children's lives.

The popular press seems to believe that there is a generational gap between parents and their children and that today's children are more technologically savvy. If this popular belief is true, then it raises a question: who is teaching our children about technology? Is it the Schools, the Media, Peer-groups, or Parents? In other words, who is actually socializing our children to technology?

So, how do we become who we are? How do we develop habits and norms? How do we become interested in various hobbies? How do we develop attitudes and perhaps skills in certain areas? This is called socialization. Socialization includes not only the process of developing habits and norms about a particular trait but also involves the purveyors of the attitudes and behaviors of the trait. These are called socialization agents and include parents, peers, media, such as television and newspapers, and schools among others.

While prior research in consumer socialization (Bao, Fern, \& Sheng, 2007; Lueg \& Finney, 2007; Moschis \& Churchill, 1978; Moschis, Moore, \& Smith, 1983) and credit socialization (Pinto, Parente, \& Mansfield, 2005) identify parents as the most influential socialization agent, given the dramatic changes in technology over the past decade, is it reasonable to assume that parents would also be the prime source in technological socialization? Are parents as "in tune" with technology and the internet as they are with the notion of shopping or the use of credit? 

the internet.

To begin to address this question this paper examines adolescents' socialization as it relates to the use of

\section{BACKGROUND}

\subsection{Socialization}

Socialization has been defined as " the process by which we learn the ways of a given society or social group so that we can function within it" (Elkin \& Handel, 1989, p. 2). Socialization is further defined by its goals. As stated by Arnett (1995), there are three goals which include impulse control and development of a conscience, role preparation and performance, and the identification of what is important with respect to the group. Identification of the important aspects to the group will enable a person to be socialized or to join the group.

Arnett (1995) proposed that two phenomena of socialization exist. One is broad socialization which promotes independence and individualism. He calls it broad since it can produce a wide range of outcomes or behaviors by the person who is socialized. Narrow socialization, on the other hand, is designed to produce conformity. Those socialized narrowly would exist and be defined by a more specific lens.

While socialization is a process that occurs throughout our lives, primary socialization theory identifies concepts of primary and secondary socialization. Primary socialization takes place as a child or adolescent (Jenkins, 2000; Oetting, Donnermeyer, \& Deffenbacher, 1998) and mostly occurs through the family or near agents. Secondary socialization occurs continually throughout our lives as we encounter different groups that which we would like to join. Secondary socialization is likely to occur through external agents such as media or organizations.

\subsection{Socialization Applications}

Consumer socialization is a concept in marketing that defines how we learn to become consumers and who teaches us. Consumer socialization is defined in many ways. The knowledge, attitudes, and skills are learned in a forum of primary socialization in which individuals learned as children while growing up. Also, there is exposure as secondary socialization from exposure to media, school, and other external influences.

Consumer socialization has been a widely studied topic for many years (see for example Bao, et al., 2007; Lueg \& Finney, 2007). Earlier work by Moschis and Churchill (1978) on consumer socialization found that consumer behavior was learned during the pre-adult years through the influence of various socialization agents with the conclusion that parents were the agents who had the most influence on consumer socialization.

Credit socialization was a natural outgrowth of consumer socialization (see for example Lea, Webley, \& Walker, 1995; Palmer, Pinto, \& Parente, 2001; Pinto, et al., 2005). Pinto, Parente, and Mansfield (2005) found that parents have the greatest influence on the credit socialization of college students.

If parents are the main socialization agents for consumer or shopping behavior and credit usage, can we assume that parents will also be the main socialization agents for technology? The growth and availability of technology has afforded students a variety of opportunities. Kim and Kamil (2004) report on adolescents, computer technology and literacy. They studied technological innovations and the transformations of traditional boundaries for the lives of young people. Students and particularly adolescents are large users of not only the internet but of social networking technologies such as Facebook, Myspace, and Xanga, to name a few (Hargittai, 2007; Subrahmanyam \& Greenfield, 2008).

There is a documented increased use of computers at home where we can presume parents have significant influence. In 2000 more than 56\% of U.S. households were reported to have computers (Current Population Survey, 2001, pp., Table 1A). In fact, in households with 15-17 year olds, more than $76 \%$ had a computer and over $68 \%$ had the internet at home (Current Population Survey, 2001, pp., Table 2A). Additionally, nine of ten school age children have access to a computer. The 2000 census also reported that in 1997, more than half of all people employed in the United States were using computers at work. 
Technology studies, such as computer-assisted instruction studies, were done in primary grades in the late 1990s (Reinking, 1988; Reinking \& Rickman, 1990; Weller, Carpenter, \& Holmes, 1998). Numerous other studies suggest that technology application to writing is influenced by learner, instructional, and task variables (Rosenbluth \& Reed, 1992). Much of the research in technology or computer socialization identifies the importance of considering adolescents' attitudes toward computers. The work by Kim and Kamil (2004) points toward the elimination over time of some of these mediating variables. The one issue remaining is the notion that students can be encouraged in the classroom to have a positive outlook toward technology. One study (Campbell, 1988) found that access to computers in either home or school lead to a lower level of anxiety toward technology.

Given the extensive work on socialization, it is appropriate to discuss where adolescents obtain information about computers, or who are the socialization agents? The agents for socialization, in general, have been clearly delineated over the past 30 years as parents, family members, media, peers and educational institutions (Churchill \& Moschis, 1979; Moschis \& Churchill, 1978; Moschis, et al., 1983; Olshavsky \& Granbois, 1979). Given the significant change in technology and the internet, it is reasonable to investigate the socialization process and particularly the socialization agents for technology using the bases of prior work. We can investigate not only a general socialization to technology but also look at specific internet uses and their major socialization agents.

\subsection{Research Questions}

This study will answer several research questions. The first general question is:

R1: Who are the socialization agents who provide the most information about the internet?

Specifically, with respect to the internet uses, the questions are:

R2: Is there a significant difference between the agents in the amount of information about the internet that they provide to adolescents?

R3: Is there a significant difference between the agents in the amount of information provided for information searching to adolescents?

R4: Is there a significant difference between the agents in the amount of information provided for purchase of products to adolescents?

R5: Is there a significant difference between the agents in the amount of information provided for entertainment purposes to adolescents?

R6: Is there a significant difference between the agents in the amount of information provided about online communications to adolescents?

\section{RESEARCH METHOD}

Surveys were administered by the researchers to convenience samples of high school students attending a summer program $(n=154)$. The students were selected from a northeastern state with the criteria of both high interest and ability across the entire state. Human subjects' institutional research board approval was obtained including parental consent as appropriate.

There were 154 surveys distributed with 136 valid responses. Of these, $80 \%$ of the students were Caucasian with the remainder of various other ethnicities. The sample was $68.5 \%$ male and over $90 \%$ of the total sample was 16 or 17 years old with a few outliers under 16 or over 17.

Socialization agents are the sources of information about the specific area of group membership and have been used in many prior studies. The conventional agents as defined in prior literature (see for example Arnon, et al., 2008; Moschis \& Churchill, 1978) are parents, peers, school, and media. Respondents were asked in this study to assess the amount of information provided from each of the following: parents, school, media, peers, and personal experience. We included personal experience since it seemed obvious that many students may have had experience on a computer without supervision. 
Paired sample t-tests were used to identify the significant differences between each pair of agents for each usage.

\section{RESULTS}

The first research question was: Who are the socialization agents who provide the most information about the internet? Descriptive statistics were calculated and are shown in Table 1. The results show that for each specific use of the internet, there is a different amount of information provided. Further, there is a different ranking for each of the internet uses. Adolescents perceive that Personal Experience provides the most information on three of the five internet uses, information search (5.98), entertainment (4.94), and communications (5.15). School provides the most information on general internet knowledge (4.99) and Media provides the most knowledge on product purchase (5.08). The least amount of information is provided by Parents in general internet knowledge (3.43) and communications (2.50) while School provides the least amount of knowledge for entertainment (2.95) and product purchase (2.01) and media agents provide the least information for information searching.

Table 1 Means of Internet Knowledge and Uses Provided by Socialization Agents

\begin{tabular}{lccccc}
\hline \multicolumn{1}{c}{$\begin{array}{c}\text { Mean } \\
\text { (7 pt. scale) }\end{array}$} & Parents & $\begin{array}{c}\text { Personal } \\
\text { Experience }\end{array}$ & Peers & Media & School \\
\hline Internet Knowledge & 3.43 & 4.29 & 4.36 & 4.83 & 4.99 \\
Information Search & 4.00 & 5.98 & 3.53 & 2.57 & 3.80 \\
Product Purchase & 3.36 & 3.89 & 3.04 & 5.08 & 2.01 \\
Entertainment & 4.43 & 4.94 & 4.46 & 3.18 & 2.95 \\
Communications & 2.50 & 5.15 & 4.11 & 4.76 & 4.04 \\
\hline
\end{tabular}

With respect to research question 2, is there a significant difference between the agents in the amount of information they provide to students, Table 2 reports the paired sample t-tests which answer the question. The amount of information learned from parents is significantly lower than any of the other socialization agents ( $\mathrm{p} \leq .001$ in each of the four paired comparisons). Further, school is a significantly greater source of information than either peers $(\mathrm{t}=2.57 ; \mathrm{p} \leq .05)$, personal experience $(\mathrm{t}=2.80 ; \mathrm{p} \leq .01)$, or parents $(\mathrm{t}=5.89 ; \mathrm{p} \leq .001)$. The only other pair that is significantly different is peers and media $(\mathrm{t}=2.35 ; \mathrm{p} \leq .05)$.

Table 2 Paired Sample t-Tests of Socialization Agents for Internet Knowledge

\begin{tabular}{|c|c|c|c|c|c|c|}
\hline Source & Mean & SD & School & Media & Peers & $\begin{array}{c}\text { Personal } \\
\text { Experience }\end{array}$ \\
\hline & $\mathrm{N}=136$ & & & t-value (sig.) & & \\
\hline School (teachers or courses) & 4.99 & 1.96 & & & & \\
\hline Media (TV, radio, books, etc.) & 4.83 & 1.94 & .87 & & & \\
\hline Peers & 4.36 & 1.89 & $2.57 *$ & $2.35^{*}$ & & \\
\hline $\begin{array}{l}\text { Personal Experience (on the } \\
\text { internet) }\end{array}$ & 4.29 & 2.11 & $2.80 * *$ & 1.88 & .25 & \\
\hline Parents & 3.43 & 2.02 & $5.89 * * *$ & $5.34 * * *$ & $3.73 * * *$ & $3.62 * * *$ \\
\hline
\end{tabular}

With respect to research question 3 , is there a significant difference between the agents in the amount of information they provide for information search to students, Table 3 reports the paired sample t-tests. The amount of information learned from Media is significantly lower than any of the other socialization agents $(\mathrm{p} \leq .001 \mathrm{in}$ each of the four paired comparisons). Further, Personal Experience is a significantly greater source of information than any of the other agents (parents $(\mathrm{t}=10.51 ; \mathrm{p} \leq .001)$, school $(\mathrm{t}=10.51 ; \mathrm{p} \leq .001)$, peers $(12.44 ; \mathrm{p} \leq .001)$, or media $(\mathrm{t}=19.66 ; \mathrm{p} \leq .001)$. The only other pair that is significantly different is parents and peers $(\mathrm{t}=2.33 ; \mathrm{p} \leq .05)$. 
Table 3 Paired Sample t-Tests of Socialization Agents for Information Search

\begin{tabular}{|c|c|c|c|c|c|c|}
\hline Source & Mean & SD & $\begin{array}{c}\text { Personal } \\
\text { Experience }\end{array}$ & Parents & School & Peers \\
\hline & $\mathrm{N}=136$ & & & ue (sig.) & & \\
\hline $\begin{array}{l}\text { Personal Experience (on the } \\
\text { internet) }\end{array}$ & 5.98 & 1.34 & & & & \\
\hline Parents & 4.00 & 1.79 & $10.51 * * *$ & & & \\
\hline School (teachers or courses) & 3.80 & 2.17 & $10.51 * * *$ & .86 & & \\
\hline Peers & 3.53 & 1.83 & $12.44 * * *$ & $2.23 *$ & 1.31 & \\
\hline Media (TV, radio, books, etc.) & 2.57 & 1.68 & $19.66 * * *$ & $7.05 * * *$ & $6.10 * * *$ & $5.93 * * *$ \\
\hline
\end{tabular}

With respect to research question 4 , is there a significant difference between the agents in the amount of information they provide to students for product purchase,

Table 4 reports the paired sample t-tests which answer this question. The amount of information learned from school is significantly lower than any of the other socialization agents $(p \leq .001$ in each of the four paired comparisons). Media is a significantly greater source of information than all other sources: personal experience $(\mathrm{t}=4.42 ; \mathrm{p} \leq .001)$; parents $(\mathrm{t}=7.43 ; \mathrm{p} \leq .001)$; peers $(\mathrm{t}=9.40 ; \mathrm{p} \leq .001)$; or school $(\mathrm{t}=15.74 ; \mathrm{p} \leq .001)$. Additionally, personal experience is significantly greater than parents $(\mathrm{t}=2.07 ; \mathrm{p} \leq .05)$, peers $(\mathrm{t}=3.71 ; \mathrm{p} \leq .001)$, or school $(\mathrm{t}=8.71$; $\mathrm{p} \leq .001)$.

Table 4 Paired Sample t-Test of Socialization Agents for Product Purchase

\begin{tabular}{|c|c|c|c|c|c|c|}
\hline Source & Mean & SD & Media & $\begin{array}{c}\text { Personal } \\
\text { Experience }\end{array}$ & Parents & Peers \\
\hline & $\mathrm{N}=136$ & & & t-value (sig.) & & \\
\hline Media (TV, radio, books, etc.) & 5.08 & 2.07 & & & & \\
\hline $\begin{array}{l}\text { Personal Experience (on the } \\
\text { internet) }\end{array}$ & 3.89 & 2.21 & $4.42 * * *$ & & & \\
\hline Parents & 3.36 & 1.86 & $7.43 * * *$ & $2.07 *$ & & \\
\hline Peers & 3.04 & 1.96 & $9.40 * * *$ & $3.71 * * *$ & 1.48 & \\
\hline School (teachers or courses) & 2.01 & 1.46 & $15.74 * * *$ & $8.71 * * *$ & $7.21 * * *$ & $5.27 * * *$ \\
\hline
\end{tabular}

Research question 5 deals with the amount of information provided by socialization agents for entertainment.

Table 5 reports the paired sample t-tests which answer the question. Personal experience provides more information than peers $(\mathrm{t}=2.37 ; \mathrm{p} \leq .05)$, media $(\mathrm{t}=9.01 ; \mathrm{p} \leq .001)$, or school $(\mathrm{t}=8.14 ; \mathrm{p} \leq .001)$. Peers provide more information than media $(\mathrm{t}=3.98 ; \mathrm{p} \leq .001)$ or school $(\mathrm{t}=7.67 ; \mathrm{p} \leq .001)$ with respect to entertainment. Finally, parents provide significantly more information about entertainment than either media $(\mathrm{t}=7.44 ; \mathrm{p} \leq .001)$ or $\mathrm{school}(\mathrm{t}=6.88 ; \mathrm{p} \leq$ .001). Conversely, school provides significantly less information than personal experience, peers, or parents.

Table 5 Paired Sample t-Test of Socialization Agents for Entertainment

\begin{tabular}{|c|c|c|c|c|c|c|}
\hline Source & Mean & SD & $\begin{array}{c}\text { Personal } \\
\text { Experience }\end{array}$ & Peers & Parents & Media \\
\hline & $\mathrm{N}=136$ & & & t-value (sig.) & & \\
\hline $\begin{array}{l}\text { Personal Experience (on the } \\
\text { internet) }\end{array}$ & 4.94 & 2.07 & & & & \\
\hline Peers & 4.46 & 1.99 & $2.37 *$ & & & \\
\hline Parents & 4.43 & 2.39 & 1.73 & .05 & & \\
\hline Media (TV, radio, books, etc.) & 3.18 & 2.05 & $9.01 * * *$ & $3.98 * * *$ & $7.44 * * *$ & \\
\hline School (teachers or courses) & 2.95 & 1.77 & $8.14 * * *$ & $7.67 * * *$ & $6.88 * * *$ & 1.04 \\
\hline
\end{tabular}


There is also a difference in the amount of information provided by socialization agents for communication.

Table 6 illustrates the significant difference between pairs of agents. Parents provide significantly less information than all other agents: personal experience $(\mathrm{t}=12.07 ; \mathrm{p} \leq .001)$; media $(\mathrm{t}=10.66 ; \mathrm{p} \leq .001)$; school $(\mathrm{t}=6.54$; $\mathrm{p} \leq .001)$; or peers $(\mathrm{t}=6.52 ; \mathrm{p} \leq .001)$. Personal experience provided significantly more information than parents, peers $(\mathrm{t}=5.46 ; \mathrm{p} \leq .001)$, school $(\mathrm{t}=3.88 ; \mathrm{p} \leq .001)$, or parents $(\mathrm{t}=12.07 ; \mathrm{p} \leq .001)$. Also, media provides significantly more information about communication than peers $(\mathrm{t}=2.40 ; \mathrm{p} \leq .05)$, schools $(\mathrm{t}=3.64 ; \mathrm{p} \leq .001)$, or parents $(\mathrm{t}=10.66$; $\mathrm{p} \leq .001)$.

Table 6 Paired Sample t-Test of Socialization Agents for Communication

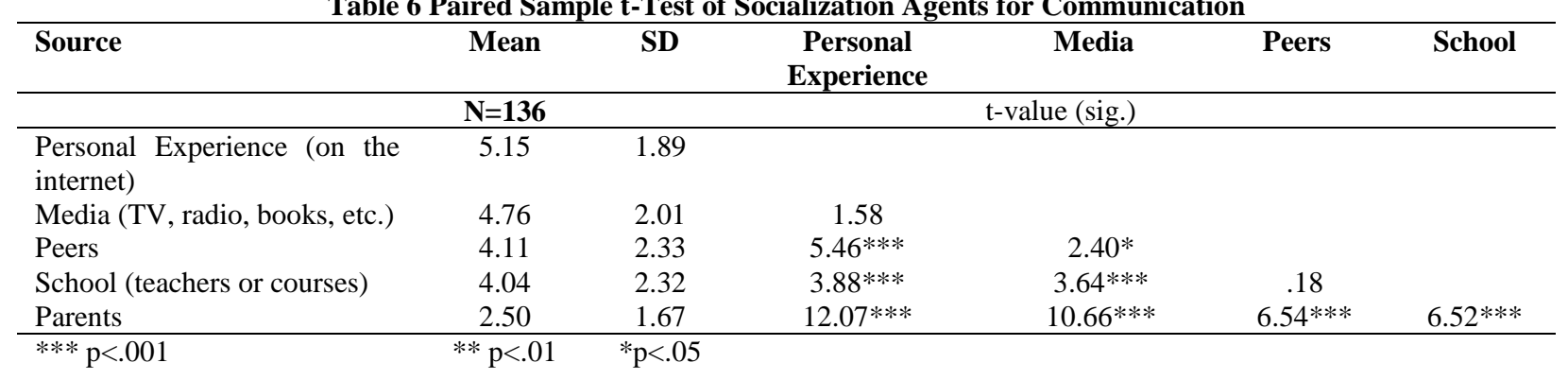

\section{DISCUSSION} depends".

So, what is, in fact, the answer to this study? Who is teaching our children? The answer is that "it all

There are several significant findings of our study as they relate to the identification of the socialization agents. First, as we may have expected, parents do not play a significant role in teaching their children about the internet. Even with increasing access to computers in the home, parents provide significantly less information than any other source. This may be due to a generational or age gap. Adolescents have grown up with computers. Unlike their parents, they have been exposed to computers at a very early age. It is increasingly common for young children to see parents at home with a computer, for more of their daily transactions such as shopping to be done on the internet, and for children to receive a computer (with learning programs) at a young age. Thus, children should be more likely to learn about technology, computers, and the internet from their parents in the future. However, our sample was 16-17 year olds with most parents who were likely to be in their 40's. The parents were not raised with computers and are not as likely to exude proficiency as younger parents.

Personal Experience as a socialization agent is higher than any other agent when it comes to most specific uses of the internet, such as searching for information, communication, and entertainment. Adolescents are likely to engage in trial by error in internet usage. We might also suspect that while the youth are comfortable searching on the internet by themselves, they may also be less apt to ask their parents to help. They may feel that they already know more about the internet than their parents.

The specific use that does not fit the proposition is the use of the internet for purchasing product. It is interesting that the main socialization for purchasing on the internet is the media. The inclusion of the internet address for virtually any product advertised on television, radio, or print media probably accounts for the media as the main socialization agent.

Our data show that technology socialization is accomplished via personal experience to a large extent especially when the internet usage is specific, such as for entertainment, communication, of information search. General internet knowledge is most informed by schools and media. Therefore, it is important to be directive in our children's personal experiences. We should help to shape the attitudes, knowledge, and behaviors of our students in technology. This may be accomplished by educating parents to be proactive in their children's experience with technology to be sure to pass along appropriate information to them. 
The outcome of this study should be a deliberate program to socialize our children to technology that is dominated by the students themselves and much more difficult to direct. Perhaps the model is much like the drug and alcohol awareness programs implemented throughout the United States.

This study's message is a simple one. Since the use of the internet has become ubiquitous over the past few years, it is important to find out the real source of our children's education in this arena. If we know the source, we can help to direct the message in a positive way.

\section{LIMITATIONS AND FUTURE RESEARCH}

There are several limitations in this study. We only looked at socialization agents. We may look further at the specific internet usage to see if there are differences by agent. Are there relationships specifically in what they are doing and who socialized them? Do their prior dispositions - for example primary areas of interest in terms of hobbies or abilities, change the perceived agents?

Finally, since we investigated high school students, we can ask if there is a difference in age group? Perhaps we can repeat over time? Is there a relationship with the age of the parent? As parents are more a part of the internet generation, are they likely to provide more information to their children?

\section{AUTHOR INFORMATION}

Diane H. Parente, Ph.D. is Professor of Management in the Black School of Business at Penn State Erie, The Behrend College. She received her PhD from the University at Buffalo. She has extensive industry experience logistics, operations, management information systems, and strategic business unit management. Her research interests revolve around the cross-functional aspects of business. She has published in numerous journals including Information Resources Management Journal, Interfaces, IJOPM, and the Communications of the ACM. She also has authored a book on Best Practices in Online Procurement Auctions. Dr. Parente is a member of the Academy of Management, DSI, and POMS.

Matthew Swinarski, Ph.D. is Assistant Professor of MIS in the Black School of Business at Penn State Erie, The Behrend College. He received his Ph.D. from the University at Buffalo. His active research areas are IS sourcing and IS education. His papers have been published in Communications of the ACM, Decision Support Systems, Communications of the AIS and Advances in Management Information Systems, and he has presented his research at numerous conferences including ICIS, AMCIS, HICSS, and DSI. He was also Issue Managing Editor for the Journal of Information Technology Theory and Application. His industry experience includes installation, configuration, and service contact management of enterprise applications.

Kathleen Noce, D.Ed. is Lecturer in MIS in the Black School of Business at Penn State Erie, The Behrend College. She received her D.Ed. from Indiana University of Pennsylvania. Her research interests include Internet issues related to marketing, social concerns and e-commerce, information systems and technological leadership. Her work has appeared in the Journal of Behavioral Studies in Business. She has also presented her research at numerous conferences including DSI, MWDSI, and the Academy of Management. Dr. Noce has previous industry experience in systems analysis and design in the financial sector and information technology management.

\section{REFERENCES}

1. Arnett, J. J. (1995). Broad and narrow socialization: The family in the context of a cultural theory. Journal of Marriage and the Family, 57(3), 617-628.

2. Arnon, S., Shamai, S., \& Ilatov, Z. (2008). Socialization agents and activities of young adolescents. Adolescence, 43(170), 373-397.

3. Bao, Y., Fern, E. F., \& Sheng, S. (2007). Parental style and adolescent influence in family consumption decisions: An integrative approach. Journal of Business Research, 60(7), 672-680.

4. Campbell, N. J. (1988). Correlates of computer anxiety of adolescent students. Journal of Adolescent Research, 3, 107-117. 
5. Churchill, G. A., \& Moschis, G. P. (1979). Television and Interpersonal Influences on Adolescent Consumer Learning. Journal of Consumer Research, 6(1), 22-35.

6. Clugston, M., Howell, J. P., \& Dorfman, P. W. (2000). Does Cultural Socialization Predict Multiple Bases and Foci of Commitment? Journal of Management, 26(1), 5-30.

7. Current Population Survey (2001).

8. Dedovic, K., Wadiwalla, M., Engert, V., \& Pruessner, J. C. (2009). The Role of Sex and Gender Socialization in Stress Reactivity. Developmental Psychology, 45(1), 45-55.

9. Dill, K. E., \& Thill, K. P. (2007). Video Game Characters and the Socialization of Gender Roles: Young People's Perceptions Mirror Sexist Media

10. Depictions. Sex Roles, 57, 851-864.

11. Elkin, F., \& Handel, G. (1989). The child and society: The process of socialization (5th ed.). New York: McGraw Hill.

12. Ellis, G. J., Lee, G. R., \& Petersen, L. R. (1978). Supervision and Conformity: A Cross-Cultural Analysis of Parental Socialization Values. The American Journal of Sociology, 84(2), 386-403.

13. Fondas, N., \& Wiersema, M. (1997). Changing of the guard: The influence of CEO socialization on strategic change. The Journal of Management Studies, 34(4), 561-584.

14. Gómez, L. F. (2009). Time to socialize: Organizational socialization structures and temporality The Journal of Business Communication, 46(2), 179-207.

15. Hargittai, E. (2007). Whose space? Differences among users and non-users of social network sites Retrieved June 10, 2009: http://jcmc.indiana.edu/vol13/issue1/hargittai.html

16. Jenkins, R. (2000). Categorization: Identity, Social Process and Epistemology. Current Sociology, 48(3), 725.

17. Kim, H. S., \& Kamil, M. L. (2004). Adolescents, computer technology, and literacy. In T. L. Jetton \& J. A. Dole (Eds.), Adolescent literacy research and practice (pp. 351-368). New York: Guilford Press.

18. Klein, H. J., Fan, J., \& Preacher, K. J. (2006). The effects of early socialization experiences on content mastery and outcomes: A mediational approach. Journal of Vocational Behavior, 68(1), 96-115.

19. Lea, S. E. G., Webley, P., \& Walker, C. M. (1995). Psychological factors in consumer debt: Money management, economic socialization, and credit use. Journal of Economic Psychology, 16(4), 681-701.

20. Long, T. E., \& Hadden, J. K. (1985). A reconception of socialization. Sociological Theory, 3(1), 39-49.

21. Lueg, J. E., \& Finney, R. Z. (2007). Interpersonal communication in the consumer socialization process: Scale development and validation. Journal of Marketing Theory and Practice, 15(1), 25-39.

22. Moschis, G. P., \& Churchill, G. A. (1978). Consumer Socialization: A Theoretical and Empirical Analysis. Journal of Marketing, 15, 599-609.

23. Moschis, G. P., Moore, R. L., \& Smith, R. B. (1983). The Impact of Family Communications on Adolescent Consumer Socialization. Paper presented at the Association for Consumer Research, Provo, UT.

24. Oetting, E., Donnermeyer, J., \& Deffenbacher, J. (1998). Primary socialization theory. The influence of the community on drug use and deviance. Substance Use Misuse, 33(8), 1629-1665.

25. Olshavsky, R. W., \& Granbois, D. H. (1979). Consumer Decision Making-Fact or Fiction? The Journal of Consumer Research, 6(2), 93-100.

26. Palmer, T. S., Pinto, M. B., \& Parente, D. H. (2001). College Students' Credit Card Debt and the Role of Parental Involvement: Implications for Public Policy. Journal of Public Policy \& Marketing, 20(1), 105113.

27. Petersen, L. R., Lee, G. R., \& Ellis, G. J. (1982). Social Structure, Socialization Values, and Disciplinary Techniques: A Cross-Cultural Analysis. Journal of Marriage and the Family, 44(1), 131-142.

28. Pinto, M. B., Parente, D. H., \& Mansfield, P. (2005). Information Learned from Socialization Agents: Its Relationship to Credit Card Usage. Family and Consumer Science Research Journal, 33(4), 357-367.

29. Reinking, D. (1988). Computer-mediated text and comprehension differences: The role of reading time, reader preference, and estimation of learning. Reading Research Quarterly, 23, 484-498.

30. Reinking, D., \& Rickman, S. S. (1990). The effects of computer-mediated texts on the vocabulary learning and comprehension of intermediate-grade readers. Journal of Reading Behavior, 22, 395-411.

31. Rosenbluth, G. S., \& Reed, W. M. (1992). The effects of writing-process-based instruction and word processing on remedial and accelerated 11th graders Computers in Human Behavior(42), 71-95.

32. Spera, C., \& Matto, H. C. (2007). A contextual-congruence model of socialization. Families in Society, 88(4), 551-560. 
33. Subrahmanyam, K., \& Greenfield, P. (2008). Online communication and adolescent relationships. The Future of Children: Children and Electronic Media, 18(1), 119-146.

34. Tinsley, B. J. (1992). Multiple Influences on the Acquisition and Socialization of Children's Health Attitudes and Behavior: An Integrative Review. Child Development, 63(5), 1043-1069.

35. Weller, L. D., Carpenter, S., \& Holmes, C. T. (1998). Achievement gains of low-achieving students using computer-assisted vs regular instruction. Psychological Reports, 83(4), 1440-1441.

\section{NOTES}


NOTES 